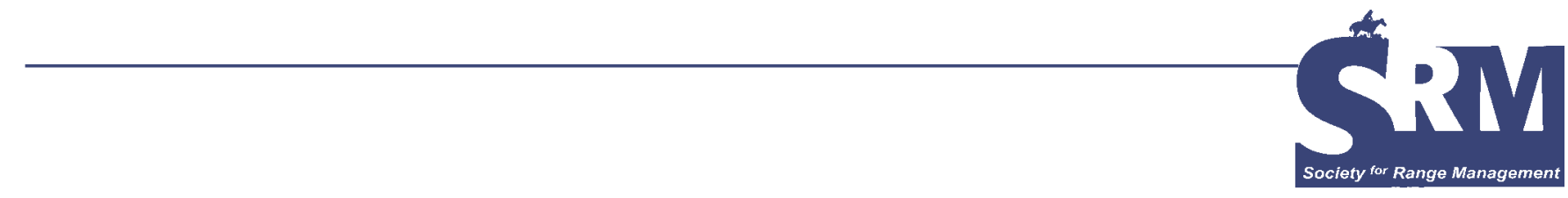

\title{
New Mexico's Range Research: From Territorial Days to the Digital Age
}

\section{By Rex D. Pieper and Susan Pieper}

\begin{abstract}
It is possible by looking at a range to tell how it has been treated. The number and kind of range weeds, the kinds and abundance of grasses, the condition of the shrubbery, the amount and character of the erosion features, all taken together with an appreciation of the common or typical condition of the locality in question, tell the story of what the range has been, and hence what it may be again by proper treatment. [E. O. Wooton, 1904]
\end{abstract}

The story of range research in New Mexico begins with Professor E. O. Wooton, a botanist who was one of New Mexico A\&M's first faculty members after the school was founded in 1888. According to Kelly Allred's article, "The Trail of E.O. Wooton," in the spring 1993 edition of New Mexico Resources magazine, Wooton "established himself as the premier, if not the only, resident botanist in the Territory of New Mexico, becoming well known not only to the citizenry of ranchers and farmers, but also to the Eastern establishment of plant scientists." Wooton was also employed for several summers as a range investigator, appraising range conditions for the USDA's Division of Agrostology.

Allred's article focused on Wooton's 1,200-mile journey from Las Cruces to northern New Mexico and southern Colorado in July and August, 1904. On the trip, Wooton collected plants in his role as Experiment Station botanist, but added observations concerning range conditions, as well as grazing practices. Based on what he had learned not only in the 1904 trip, but also years of observation throughout the Territory, in 1908 Wooton summarized his assessment of New Mexico rangelands in an Experiment Station Bulletin titled The Range Problem in New Mexico, which set the stage for a century of range research in New Mexico.

Although Wooton left New Mexico in 1911 to take a position in Washington, DC, his foresight culminated in the establishment in 1912 of the 193,000-acre Jornada Range Reserve north of Las Cruces, under the jurisdiction of the USDA's Bureau of Plant Industry.

\section{Jornada Experimental Range}

The Jornada Range Reserve became the Jornada Experimental Range in 1927 and was later transferred to the research branch of the US Forest Service in 1915.

Early researchers at the Jornada were ecologists who focused on the desert environment. Dr R. S. Campbell wrote several early articles on plant succession on the range, and R. H. Canfield made a major contribution to the field of range research by designing methods for determining cover and composition. During the same period, drought stresses on livestock led to studies involving livestock, including one by Wooton on emergency feed.

The Jornada was an ideal location for long-term studies and early scientists established permanent areas for studying vegetation changes. Black grama quadrats established as 


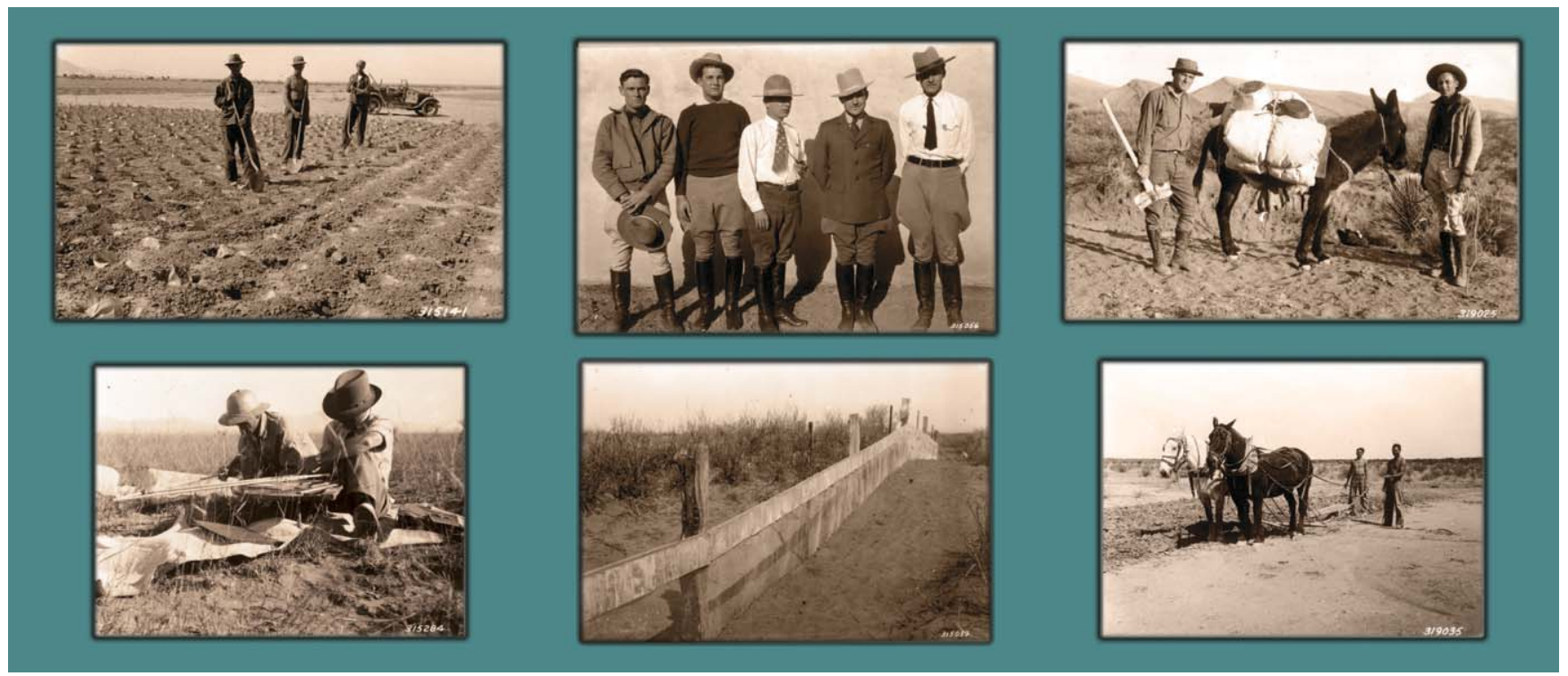

early as 1915 exist on the range today. E. W. Nelson used these sites to demonstrate changes in basal area of black grama from 1915 to 1927, and these data were extended to 1952 by Bud Paulsen and Fred Ares. Over time, these studies have been used to demonstrate the influence of precipitation on vegetation in the Chihuahuan Desert.

When the Jornada was transferred to the USDA Agricultural Research Service (ARS) in 1954, Dr Carlton Herbel became research leader, a position he would hold for the next $30 \mathrm{yr}$. He believed that experiments involving direct manipulation of vegetation were necessary because the desert ranges responded so slowly to grazing management alone. Under his leadership, extensive studies on mechanical and chemical methods of controlling the main shrubby speciesmesquite, tarbush, and creosotebush-were conducted. Herbel and his graduate students also carried out significant studies demonstrating that soil surface temperature, in addition to soil water content and competition from shrubs, controlled grass seeding success.

Using land surveys initiated in 1858, Herbel and graduate student Lee Buffington chronicled changes in the Jornada's vegetation from grassland to shrubland. This classic study with its associated maps has served as a benchmark for many subsequent publications. Herbel's interest in the influence of soil characteristics and water content led to studies with Drs Robert Gibbens and Leland Gile on soil water fluctuations and soil variations in the Jornada Basin. Herbel also summarized and published results of work on mesquite management and vegetation changes on the Jornada following the 1950s drought. He collaborated with Dr Arnold Nelson of New Mexico State University (NMSU) Department of Animal and Range Sciences on studies of the diets and grazing habits of Santa Gertrudis cattle.
Under Herbel's supervision, Dr Dean Anderson conducted large-scale grazing studies, including short-duration grazing trials. When sheep were added to the livestock mix, Anderson and Dr Clarence Hulet from the ARS Sheep Station in Dubois, Idaho, initiated studies on the behavior of cattle and sheep grazing together, at first seeking to protect sheep from predators by bonding them to cattle. Other studies on sheep diets and alternative means of protection from predators ensued.

Following Herbel's retirement in the mid 1980s, Dr Kris Havstad from Montana State University, a former NMSU graduate, assumed the Jornada's leadership. Although his specialty was range nutrition, Havstad was well grounded in all aspects of range ecology. The Jornada Basin Long Term Ecological Research Program had been established in 1982 as a Desert Grassland Site under the auspices of the National Science Foundation with research conducted by NMSU's Biology Department. Under Havstad's leadership, that research was consolidated with the USDA ARS. Research conducted on this "Laboratory Without Walls" is multidimensional, with contributions from scientists representing institutions from around the world, as well as many state and national organizations. Research on the Jornada, often holistic in scope, is generally focused on landscape-level processes. However, rangeland remediation research has continued on the Jornada, but on varied scales utilizing a "trigger site" concept with natural processes at smaller scales and landscape processes at much larger scales.

A second generation of scientists has also contributed to our understanding of temporal and spatial variation on the Jornada Basin. These include Drs Brandon Bestelmeyer, Joel Brown (with the Natural Resources Conservation Service), Ed Fredrickson, Jeff Herrick, Curtis Monger (Department of Plant and Environmental Science at 
NMSU), Deb Peters, Al Rango, and Sandy Tartowski. These scientists and others have led a major effort to incorporate principles of state and transition models to southern New Mexico rangelands and to develop practical inventory and monitoring procedures. Dr Walt Whitford (NMSU Biology Department and the Environmental Protection Agency) enhanced understanding of decomposition processes on Chihuahuan Desert ecosystems as well as the role of a variety of animals within those ecosystems.

\section{NMSU College Ranch/Chihuahuan Desert Rangeland Research Center}

In 1926, when Professor J. L. Lantow headed the Department of Animal Husbandry at New Mexico A\&M, the college acquired an area for rangeland research encompassing about 64,000 acres adjacent to the Jornada Experimental Range. The former college ranch is now known as the Chihuahuan Desert Rangeland Research Center (CDRRC).

Early work on the college ranch involved nutrition studies initiated by Lantow in 1930 and continued by Professors Wilbur Watkins and John Knox during the 1930s and continuing until Knox retired in 1964. Much of the nutrition work concerned supplemental cattle feeding in the winter, as well as determining livestock calcium and phosphorus requirements and the likelihood of rangeland forage to meet these requirements. Dr Arnold Nelson, who replaced Watkins in the early 1960s, continued nutrition research at the college ranch as well as on the Jornada.

Professors C. P. Wilson and J. O. Bridges pioneered seeding research at the college ranch as well at other locations in New Mexico. For several years after World War II, the only range faculty members in the Department of Animal Husbandry were Professor Ken Valentine and Dr Jon Norris, and they saw to it that research at the college ranch continued. Some of their research emphases include water spreading, chemical mesquite control, small mammal influences on rangelands, ecology of important range plants, and other ancillary studies.

In 1967 Valentine began a grazing study comparing a three-pasture, one-herd grazing system with continuous grazing. After Valentine retired, Dr Reldon Beck continued

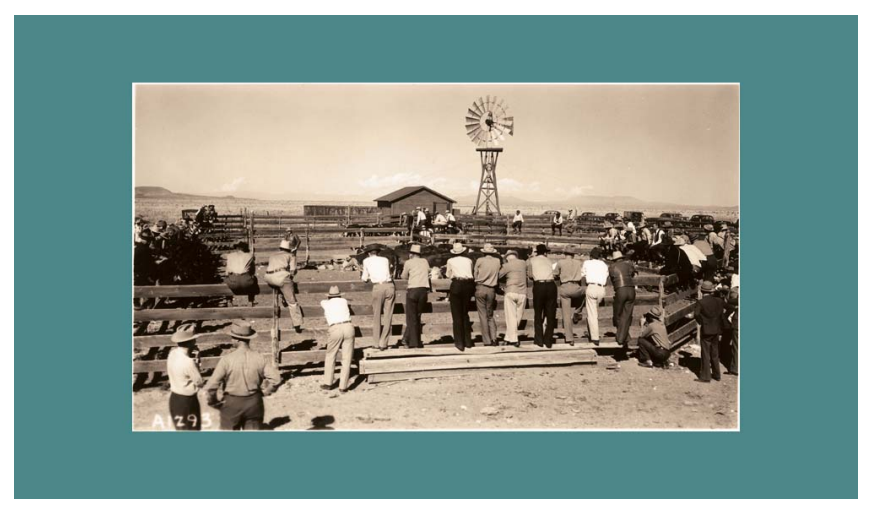

the study until 2002, and the results of this 40-yr study are presented in Bulletin 793 of the NMSU Agricultural Experiment Station. Beck also conducted extensive research on cattle and jackrabbit diets, and following Beck's retirement, Dr Derek Bailey initiated studies on cattle behavior.

Dr Jerry Holechek initiated additional grazing studies and animal diet analyses on the CDRRC and other sites across southern New Mexico. These studies focused on antiquality compounds in several range plant species and developing microhistological techniques to determine botanical composition of herbivore diets. Holechek also studied important bird and mammal habitats.

\section{NMSU Fort Stanton Cooperative Range Research Station and Corona Rangeland Research Center}

In 1963 NMSU signed an agreement with the Bureau of Land Management to conduct research on 26,000 acres at Ft. Stanton, near Capitan, New Mexico. Faculty members who participated in this research include Drs Don Dwyer, Rex Pieper, and Gary Donart in range science and Drs Arnold Nelson, Joe Wallace, and Mike Galyean in animal nutrition. Research topics at Fort Stanton included grazing, range fertilization, piñon-juniper ecology, and botanical analysis of cattle diets, as well as nutritive content of grazing cattle diets, chemical content of important forage plants, and the role of supplemental feeding in beef cattle production. Wildlife professors Drs John Wood and V. W. Howard studied wildlife on Fort Stanton, including mule deer and pronghorn ecology and management.

When research at Fort Stanton terminated in 1988, NMSU acquired a 27,830-acre ranch east of Corona, New Mexico, and research similar to that at Fort Stanton began. This time a flock of sheep was added at Corona, and extensive research on sheep nutrition and management was begun under the supervision of Dr Tim Ross. Dr Donart continued his range research on cattle grazing at Corona, and upon Dr Joe Wallace's retirement, Dr Mark Petersen continued research on range nutrition. Other researchers at Corona include Drs Kirk McDaniel (snakeweed ecology and piñon-juniper control); Dean Hawkins (reproductive physiology in cattle); Jon Boren and Louis Bender (mule deer and pronghorn ecology and management); Sam Fernald (soil water dynamics in piñon-juniper communities); Allen Torell (weather patterns at Corona, ranch values, and economics of snakeweed and piñon-juniper control); and Andres Ciblis, who succeeded Donart, continued his research, and added goats to the animals studied.

\section{NMSU Research in Other New Mexico Locations}

Wooton's plant collections and taxonomic work on New Mexico flora have been continued by Dr Rich Spellenberg (NMSU Biology Department) and Drs Steve Hatch and Kelly Allred (NMSU Animal and Range Sciences Department). 
As new range science faculty members came to NMSU in the 1970s, they initiated new kinds of research across the state of New Mexico. Dr Kirk McDaniel implemented comprehensive, detailed studies on ecology and management of troublesome range plants, examining not only control methods but also ecological changes following control. McDaniel teamed with Dr Allen Torell to develop sophisticated approaches for evaluating range improvement practices. A group of scientists, including $\mathrm{McDaniel}$, from several disciplines within NMSU's Agricultural Experiment Station and NMSU's Cooperative Extension Service joined in a task force to tackle the problem of snakeweed on New Mexico's rangeland.

Dr Karl Wood was the first watershed scientist within the Department of Animal and Range Sciences. He focused on infiltration and runoff studies under a variety of conditions including livestock grazing (both sheep and cattle), and directed comprehensive studies in western New Mexico for evaluating several methods of treating piñon-juniper slash. Dr Sam Fernald replaced Wood within the Department of Animal and Range Sciences when Wood was named director of NMSU's Water Resources Research Institute.

Other researchers at NMSU outside the Department of Animal and Range Sciences contributed further understanding of the state's range resources. Several entomologists who worked on rangeland invertebrates include Professor P. W. Cockerill, who collected and named many New Mexico insects; Dr Gordon Watts, who studied thrips on black grama and contributed to the invertebrate analysis as part of the International Biological Program's Grassland Biome project; and Drs Ellis Huddleston and John Owens, who studied range caterpillars. Dr Dave Thompson has concentrated on both native and introduced insects for snakeweed and salt cedar control.

Agricultural economists have conducted range economics research at NMSU since the 1920s and 1930s when Professors A. L. Walker, J. L. Lantow, and K. P. Pickrell evaluated livestock enterprises. After World War II, Dr James Gray analyzed range improvement practices and pioneered ranch budget analyses. When Gray retired, Drs John Fowler and Allen Torell continued with research on ranch budget analyses, and both contributed research into grazing fee determination on public lands. Fowler also studied methods for ascertaining the economics of piñonjuniper control and the economic tradeoffs between wood production and herbaceous production for livestock.

\section{US Forest Service and US Geological Survey}

In addition to the Jornada and NMSU research sites, federal agencies have sponsored range research across the state of New Mexico. US Forest Service range researchers worked out of Albuquerque in the early years. During the 1950s E. J. Dortignac led the Upper Rio Grande Unit at Albuquerque and initiated watershed studies on the Rio Puerco. By 1962 Dr Earl Aldon replaced Dortignac as research leader and continued work on watersheds and
Many individuals who contributed to range research in New Mexico have not been mentioned by name in this article. Ranch managers and workers, technicians, students, research assistants, secretaries, editors, administrators, and many others were vital members of research teams throughout the past $100 \mathrm{yr}$. The Jornada and New Mexico State University's research locations have served over 500 graduate students who used these sites as laboratories for their thesis or dissertation research.

other related rangeland issues, including ecological studies and mine reclamation research in the Four Corners area.

The person most often associated with Forest Service range research in northern New Mexico is Dr Wayne Springfield, who worked at a variety of locations. Some of his early studies examined the effectiveness of crested wheatgrass seedings, including economic studies conducted in cooperation with agricultural economists at NMSU. Springfield also concentrated on determining conditions for germination and establishment of several important New Mexico shrubs, as well as developing techniques for estimating utilization of important range grasses by counting the number of grazed plants. Springfield's research on piñonjuniper ecology also contributed to a better understanding of an important vegetation type in New Mexico.

Dr Dick Francis, Wayne Hickey, and George Garcia also worked out of the Albuquerque location. Forest Service researchers from Arizona at Fort Bayard near Silver City investigated piñon-juniper control alternatives on mule deer habitat.

By 1997, Dr Deborah Finch became project leader of the Southwest Grassland and Riparian Ecosystem Project, which focused on the Rio Grande Basin. Additional researchers on that project include ecologists Drs Paulette Ford, Rosemary Pendleton, and Burton Pendleton and social scientist Dr Carol Raish. Dr Craig Allen worked with the National Park Service and the US Geological Survey on the complexities of landscape variability at Bandelier National Monument near Los Alamos.

The Sevilleta National Wildlife Refuge 50 miles south of Albuquerque was designated as a Long Term Ecological Research Site in 1988, and research with considerable relevance for New Mexico's rangelands was conducted there under the auspices of the University of New Mexico's Biology Department.

When Dr Bob Gibbens and Rob McNeely bounced across remote sections of the Jornada Experimental Range and the CDRRC in the late 1990s and early 2000s trying to verify vegetation types shown on old maps of the region and determine current vegetational patterns, they were extending research begun as early as 1908, $4 \mathrm{yr}$ before New Mexico became a state.

Although in 1908 Wooton's vision of range research in New Mexico was to rehabilitate the grazing lands that covered most of the state, subsequent research has evolved in two directions: smaller and finer to examine processes at 
fine scales, and larger and broader to examine rangelands at landscape scales. Acquisition and analyses of the data using modern technologies such as remote sensing, computers, and global positioning systems, have enabled current researchers to understand the dynamics of New Mexico rangelands in ways never imagined by those early pioneers, but issues concerning grazing on rangelands in New Mexico will always pose a challenge for further research.
Authors are Professor Emeritus, Dept of Animal and Range Sciences, New Mexico State University, Las Cruces, NM 88003, USA, rpieper@nmsu.edu (R. Pieper); and former Editor, College of Agriculture and Home Economics, New Mexico State University, Las Cruces, NM 88003, USA (S. Pieper). Photos are from Jornada Experimental Range collection showing pre-World War II range research.

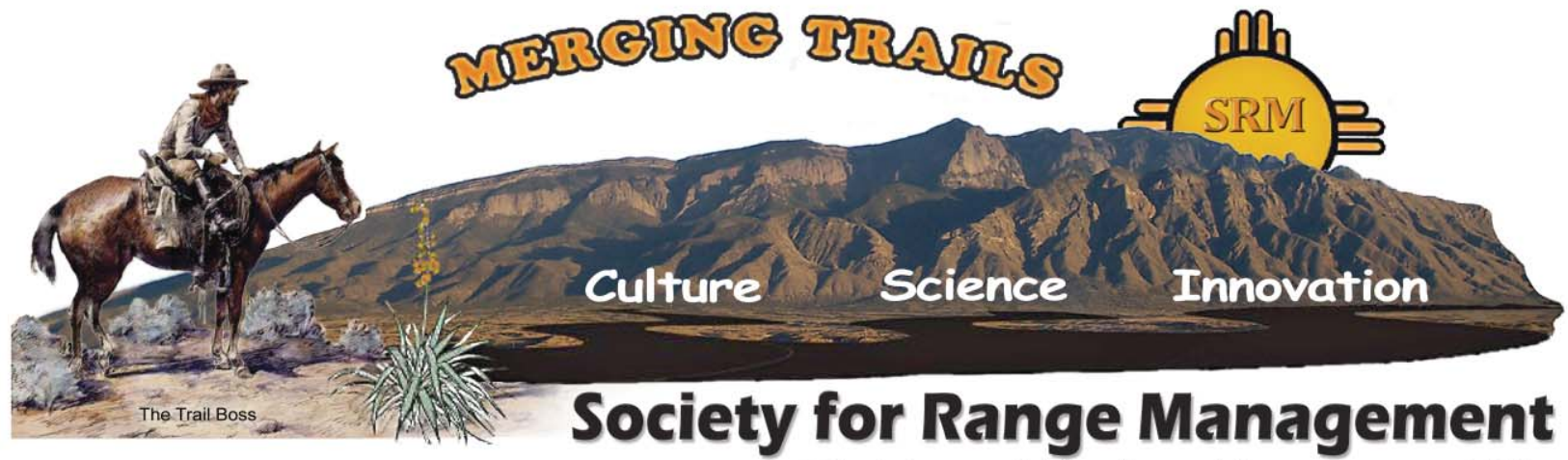

62nd Annual Meeting, Albuquerque, NM

\section{Rangeland Ecohydrology: Key Concepts and Application to State and Transition Model Development A Symposium at the 2009 Annual Meeting Tuesday, February 10, 1 pm - 5pm}

Why is rangeland vegetation always changing and how can we manage for the desired vegetation assemblages? The answers to these fundamental questions largely depend on the amount and distribution of water. This symposium will present our current understanding of feedbacks between rangeland vegetation, soils, and the water cycle. We then relate this understanding of rangeland ecohydrology to state and transition models. Theoretical advances are illustrated with experimental data of vegetation-soil-water interactions and state and transition models derived from existing rangeland sites. 